\title{
Streptococcal sepsis and incomplete Kawasaki disease in an 8 month old infant
}

\author{
K L W Hathagoda ${ }^{1}$, T Rodrigo ${ }^{1}$, *M G R S S Gunathilaka ${ }^{2}$ \\ Sri Lanka Journal of Child Health, 2018; 47(4): 362-363 \\ DOI: http://dx.doi.org/10.4038/sljch.v47i4.8610 \\ (Key words: Incomplete Kawasaki disease, Streptococcus, children)
}

The five classical clinical criteria of Kawasaki Disease (KD) are: a polymorphous exanthem, bilateral non-purulent bulbar conjunctivitis, erythema or swelling of hands/feet, lip and other oral mucosal changes, and cervical lymphadenopathy ${ }^{1}$. The first case of this unusual illness was observed by Tomisaku Kawasaki in 1961 in a 4-year-old child who presented with an unremitting fever and a rash. Even though five decades have passed, no laboratory gold standard is available. Therefore $\mathrm{KD}$ is vulnerable for underestimation depending upon the specificity of signs used for its identification ${ }^{2}$. The aetiology of Kawasaki disease remains unknown, but some epidemiological and clinical features suggest an infectious source ${ }^{3}$. Group A streptococcus [GAS] infection has been linked to $\mathrm{KD}^{4,5}$.

\section{Case report}

A previously healthy eight month old male infant was admitted to the ward at Colombo North Teaching Hospital with a two day history of fever $\left(104^{\circ} \mathrm{F}\right)$ and two episodes of brief generalized tonic clonic convulsions. On examination, he was febrile and irritable with a generalized macular-papular rash and infected wound over left shin. There was no neck stiffness. His respiratory rate was $80 / \mathrm{min}$ but on auscultation, there were no added sounds in the lungs. His heart rate was $170 / \mathrm{min}$, he was normotensive and capillary refilling time was less than 2 seconds. Full blood count showed microcytic hypochromic anaemia with thrombocytopenia (white cell count $8.5 \times 10^{3} / \mu \mathrm{L}$, haemoglobin $8.6 \mathrm{~g} / \mathrm{dl}$ and platelet count $149 \times 10^{3} / \mu \mathrm{L}$ ). C-reactive protein (CRP) was $110 \mathrm{mg} / \mathrm{dl}$ and chest $\mathrm{x}$-ray and urine analysis were normal.

\section{${ }^{1}$ Lady Ridgeway Hospital for Children, Colombo, Sri Lanka, ${ }^{2}$ Faculty of Medicine and Allied Sciences, Rajarata University of Sri Lanka \\ *Correspondence: mgrssgunathilaka@gmail.com}

(Received on 23 February 2017: Accepted after revision on 17 April 2017)

The authors declare that there are no conflicts of interest

Personal funding was used for the project.

Open Access Article published under the Creative

Commons Attribution CC-BY cC (i) License
Initially he was treated with intravenous (IV) cefotaxime and then changed to IV meropenem and vancomycin due to ongoing high fever and high CRP. He continued to have high fever and tachycardia despite antibiotic therapy. On day 3, mucosal redness was detected. Investigations on day 3 showed an erythrocyte sedimentation rate of $90 \mathrm{~mm}$ in the first hour, hypoalbuminaemia and hyponatraemia with normal liver transaminases. The ultrasound scan of the abdomen, the 2D echocardiogram and the cerebrospinal fluid analysis were normal. On day 4, his blood culture was positive for group A Streptococcus. As the organism was sensitive to crystalline penicillin, IV Penicillin was added. Due to the persistent fever and raised inflammatory markers, 2D echocardiogram was repeated but was normal with normal coronary arteries. Considering the possibility of incomplete Kawasaki disease, baby was treated with IV immunoglobulin $(2 \mathrm{~g} / \mathrm{kg})$ and acetylsalicylate. Marked clinical improvement was noted with settling of fever after IVIG therapy. Laboratory investigations showed normalization of inflammatory markers. Patient was discharged after completing a 14 day course of IV antibiotics. He was given an antithrombotic dose of aspirin and it was planned to review in 6 weeks with echocardiogram.

\section{Discussion}

This patient was initially managed as streptococcal septicaemia with IV antibiotics and then the possibility of incomplete KD was considered due to poor response and positive investigation findings. Classically KD has been defined by fever of 5 or more days along with at least four of the other principal features (changes in extremity, polymorphous rash, bilateral bulbar conjunctivitis, changes in lip or oral cavity and cervical lymphadenopathy $)^{6}$. However, there have been instances where all the major features were not met and patients were diagnosed as so-called "atypical" or "incomplete" KD and treated to prevent coronary complications. The term incomplete is preferred over atypical, because these patients do not differ much from those with classical KD except that they do not satisfy the criteria to fulfill the epidemiological case definition ${ }^{2}$.

Fever with rash and mucosal changes is consistent with $\mathrm{KD}$. Fever of $\mathrm{KD}$ is minimally responsive to 
antipyretic agents and antibiotics, and it typically remains above $101.3^{0} \mathrm{~F}^{7}$. Apart from clinical features, some laboratory test results (high CRP, low albumin and sodium, leucocytes and platelet counts) were in favor the diagnosis of incomplete KD. Notable microbiological finding was the positive blood culture for group A streptococcus, Many studies suggest that KD, like streptococcal toxic shock syndrome, is a super antigen-mediated process $^{8}$. Therefore a possible relationship between Streptococcal infections and KD should always be kept in mind. This case emphasizes the importance of considering incomplete $\mathrm{KD}$ in children with persistent fever despite appropriate antibiotic therapy for an infection which is due to an organism known to produce super-antigens.

\section{References}

1. Newburger JW, Takahashi M, Gerber MA, Gewitz MH, Tani LY, Burns JC, et al. Diagnosis, treatment, and long-term management of Kawasaki disease: A statement for health professionals from the Committee on Rheumatic Fever, Endocarditis and Kawasaki Disease, Council on Cardiovascular Disease in the Young, American Heart Association. Circulation 2004; 110(17):2747-71. https://doi.org/10.1161/01.CIR.000014514 3.19711 .78

PMid: 15505111

2. Elmer P, Pratap S, Thambireddy DR, Mendez H. Late onset sepsis and incomplete Kawasaki Disease in a 3month-old infant: A case report and literature review. International Journal of Pediatrics 2014; 3(2):51-4.

3. Burns JC, Cayan DR, Tong G, Bainto EV, Turner CL, Shike H, et al. Seasonality and temporal clustering of Kawasaki syndrome. Epidemiology 2005; 16(2): 2205. https://doi.org/10.1097/01.ede.000015290 1.06689.d4

PMid: 15703537 PMCid: PMC2894624
4. Anderson DG, Warner G, Barlow E. Kawasaki disease associated with streptococcal infection within a family. Journal of Paediatrics and Child Health 1995; 31(4):355-7. https://doi.org/10.1111/j.14401754.1995.t b00827.x

PMid: 7576898

5. Barton M, Melbourne R, Morais P, Christie C. Kawasaki syndrome associated with group A streptococcal and Epstein-Barr virus co-infections. Annals of Tropical Paediatrics 2002; 22(3):257-60. https://doi.org/10.1179/027249302125001 543

PMid: 12369491

6. Dajani A, Taubert K, Gerber M, Shulman S, Ferrieri P, Freed M. Diagnosis and therapy of Kawasaki disease in children. Circulation 1993; 87: 1776-80. https://doi.org/10.1161/01.CIR.87.5.1776 PMid: 8491037

7. Witt MT, Minich LL, Bohnsack JF, Young PC. Kawasaki Disease: More patients are being diagnosed who do not meet American Heart Association Criteria. Pediatrics 1999;104(1):e10. https://doi.org/10.1542/peds.104.1.e10 PMid: 10390296

8. Matsubara K, Fukaya T. The role of superantigens of group A Streptococcus and Staphylococcus aureus in Kawasaki disease. Current Opinion in Infectious Diseases 2007; 20(3):298-303. https://doi.org/10.1097/QCO.0b013e3280 $964 \mathrm{~d} 8 \mathrm{c}$

PMid: 17471041 